\title{
Income-, education- and gender-related inequalities in out-of-pocket health-care payments for $65+$ patients - a systematic review
}

\author{
Sandro Corrieri ${ }^{1,2^{*}}$, Dirk Heider ${ }^{1 \dagger}$, Herbert Matschinger ${ }^{3 \dagger}$, Thomas Lehnert $^{2 \dagger}$, Elke Raum ${ }^{4 \dagger}$, Hans-Helmut König ${ }^{1,2+}$
}

\begin{abstract}
Background: In all OECD countries, there is a trend to increasing patients' copayments in order to balance rising overall health-care costs. This systematic review focuses on inequalities concerning the amount of out-of-pocket payments (OOPP) associated with income, education or gender in the Elderly aged 65+.

Methods: Based on an online search (PubMed), 29 studies providing information on OOPP of $65+$ beneficiaries in relation to income, education and gender were reviewed.

Results: Low-income individuals pay the highest OOPP in relation to their earnings. Prescription drugs account for the biggest share. A lower educational level is associated with higher OOPP for prescription drugs and a higher probability of insufficient insurance protection. Generally, women face higher OOPP due to their lower income and lower labour participation rate, as well as less employer-sponsored health-care.

Conclusions: While most studies found educational and gender inequalities to be associated with income, there might also be effects induced solely by education; for example, an unhealthy lifestyle leading to higher payments for lower-educated people, or exclusively gender-induced effects, like sex-specific illnesses. Based on the considered studies, an explanation for inequalities in OOPP by these factors remains ambiguous.
\end{abstract}

\section{Background}

In all OECD countries, there is a trend to increasing patients' copayments in order to balance rising overall health-care costs [1]. Major concerns in this topic revolve around inequalities in burden for subgroups of society, being unproportionally charged for health care services because of their socioeconomic background. The difference in financial strain is displayed in a larger share of income that must be invested in health care services, leading to dissimilar efforts for comparable benefits, and disadvantages for low-income beneficiaries.

There are three major forms of copayments. Firstly, there is a varying amount that must be paid by the patient before the insurance company steps in, called deductible. Regularly, a higher deductible is associated with a lower premium, leaving the beneficiary with a

\footnotetext{
* Correspondence: Sandro.Corrieri@medizin.uni-leipzig.de

† Contributed equally

'University of Leipzig, Health Economics Research Unit, Department of

Psychiatry, Liebigstr. 26, 04103 Leipzig, Germany

Full list of author information is available at the end of the article
}

lower basic amount, but at higher risk in case of morbidity. Secondly, the co-insurance marks the amount of OOPP the beneficiary has to spend after the deductible limit is reached. The insurer only pays a stipulated percentage share of the costs, while the patient pays for the rest. Thirdly, and in the focus of this article, there are direct OOPP for health-care services. Examples are costs for prescription medications, hospital stays, alternative medicine, physiotherapy or home nursing, which are not covered by insurance policies and have to be paid by the patients themselves [2]. All three forms of copayments are suspected to evoke or reinforce inequalities in burdens for beneficiaries, especially regarding predispositions in education, sex and, foremost, income, as will be explored in this review. In the USA, copayments have been established for a long time and have caused a large body of studies, making the USA the most valuable source for literature. This may give the opportunity to outline possible future developments in Europe. The present review gives an overview of the inequalities of OOPP by the fastest growing population, 
the elderly aged $65+$, associated with income, education and sex. In the elderly, inequalities are likely to be most apparent due to extensive use of medical services caused by age-related morbidity. Purpose of this task is to provide a basis, serving as foundation for future studies focusing on the mechanisms causing the described inequalities.

\section{Methods}

\section{Search strategy}

As shown in Figure 1, an online PubMed search was conducted to identify studies. Search terms included combinations of the following keywords: "cost sharing"[All Fields] OR "copay"[All Fields] OR "copayments"[All Fields] OR "out of pocket"[All Fields] OR "direct payments"[All Fields] OR "incentive based"[All Fields] OR "patient charge"[All Fields] OR "prescription charge"[All Fields] OR "coinsurance"[All Fields] OR "deductible"[All
Fields] OR "extra billing"[All Fields] AND "aged"[MeSH Terms]. The search process ended on November $9^{\text {th }}$, 2009. Studies' abstracts were examined in detail, and, if required, extended by a full text revision.

\section{Inclusion and exclusion criteria}

Unless separate data analyses were conducted for the $65+$ subsamples, studies not limited to the senior population (defined as 65 years of age or older) were excluded. Only studies in English and German language based on evaluation of primary data were considered. Finally, articles had to contain relevant information concerning education, sex and/or income in relation to out-of-pocket payments for people 65+ (as illustrated in Figure 1).

\section{Analysis of data}

To facilitate comparisons, all cost estimates were inflated to 2008 US dollars using the Chain Type Price

PubMed search terms:

"cost-sharing", "copay", "copayments", "out of pocket", "direct payments", "incentive based", "patient charge", "prescription charge", "coinsurance", "deductible", "extra billing", "aged"

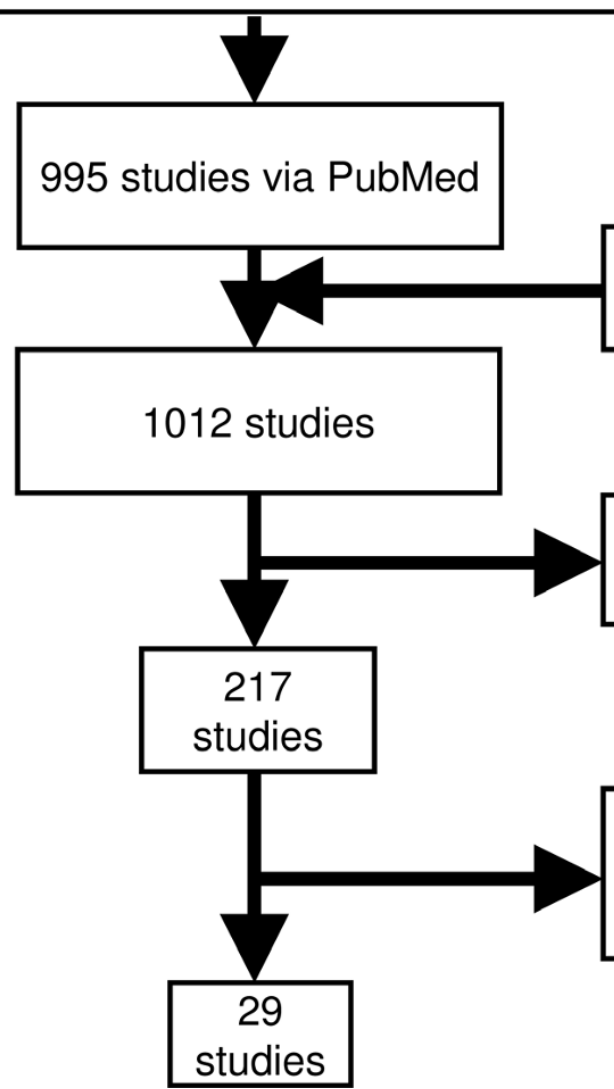

17 studies via reference lists

Contains no information on out-of-pocket payments by persons 65 years and older

Contains no information on inequalities concerning out-of-pocket costs in relation to income, education and gender of persons 65 years and older

Figure 1 diagram showing filtering process of literature used. 
Table 1 Overview of studies reviewed (in alphabetical order)

\begin{tabular}{|c|c|c|c|}
\hline Study & Sample & Study Design & Outcomes \\
\hline $\begin{array}{l}\text { Adams, Soumerai, \& } \\
\text { Ross-Degnan, 2001a }\end{array}$ & $\begin{array}{l}4439 \text { Medicare } \\
\text { beneficiaries with } \\
\text { hypertension }\end{array}$ & $\begin{array}{l}\text { national longitudinal survey (MCBS 1995); } \\
\text { inferential statistic }\end{array}$ & $\begin{array}{l}\text { Association between types of drug coverage, } \\
\text { consumption \& costs per tablet; Findings: income }\end{array}$ \\
\hline Blustein, 1995a & $\begin{array}{l}4110 \text { female Medicare } \\
\text { beneficiaries }\end{array}$ & $\begin{array}{l}\text { probability survey based on multistage, } \\
\text { stratified cluster sample of Medicare (MCBS } \\
\text { 1991-1992); multiple inferential statistic }\end{array}$ & $\begin{array}{l}\text { Use of mammography during first } 2 \text { years of } \\
\text { Medicare offered benefit; Findings: income, } \\
\text { education }\end{array}$ \\
\hline Blustein, 2000b & $\begin{array}{l}4334 \text { Medicare } \\
\text { beneficiaries with } \\
\text { hypertension }\end{array}$ & $\begin{array}{l}\text { nationally-representative face-to-face survey of } \\
\text { Medicare; multiple inferential statistic }\end{array}$ & $\begin{array}{l}\text { Sexual differences in burden for prescription drugs; } \\
\text { Findings: sex }\end{array}$ \\
\hline Chandra et al., 2007 & $\begin{array}{l}70912 \text { CalPers plan } \\
\text { members }\end{array}$ & $\begin{array}{l}\text { Panel of Medicare supplemental plan Members } \\
\text { (CalPers 2000-2003); multiple inferential statistic }\end{array}$ & $\begin{array}{l}\text { Influence \& consequences of price elasticity in } \\
\text { patient cost-sharing; Findings: income }\end{array}$ \\
\hline $\begin{array}{l}\text { Crystal, Johnson, } \\
\text { Harman, } \\
\text { Sambamoorthi, \& } \\
\text { Kumar, 2000b }\end{array}$ & $\begin{array}{l}7886 \text { Medicare } \\
\text { beneficiaries }\end{array}$ & $\begin{array}{l}\text { nationally representative survey of Medicare, } \\
\text { stratified, multistage, area probability sample } \\
\text { (MCBS 1995); multiple inferential statistic }\end{array}$ & $\begin{array}{l}\text { Overview on size, distribution \& burden of OOPP; } \\
\text { Findings: income, education }\end{array}$ \\
\hline $\begin{array}{l}\text { Davis, Poisal, Chulis, } \\
\text { Zarabozo, \& Cooper, } \\
\text { 1999a }\end{array}$ & $\begin{array}{l}12.000 \text { Medicare } \\
\text { beneficiaries }\end{array}$ & Panel Survey (MCBS 1995); descriptive & $\begin{array}{l}\text { Overview on sources \& extent of drug coverage } \\
\text { among Medicare beneficiaries; Findings: income }\end{array}$ \\
\hline Dowd et al., 1994a & $\begin{array}{l}2891 \text { Medicare } \mathrm{HMO} \& \\
\text { fee-for-service members }\end{array}$ & Survey; multiple inferential statistic & $\begin{array}{l}\text { Characteristics of Medicare beneficiaries \& influence } \\
\text { on choice of health plan; Findings: income }\end{array}$ \\
\hline $\begin{array}{l}\text { Fahlman, Lynn, } \\
\text { Doberman, Gabel, \& } \\
\text { Finch, 2006d }\end{array}$ & $\begin{array}{l}4602 \text { Medicare } \\
\text { beneficiaries }\end{array}$ & $\begin{array}{l}\text { Cross-sectional, retrospective review \& } 1990 \\
\text { Census data; multiple inferential statistic }\end{array}$ & $\begin{array}{l}\text { Drug spending by disease \& demographics in last } \\
\text { year of life; Findings: income }\end{array}$ \\
\hline $\begin{array}{l}\text { Gellad, Huskamp, } \\
\text { Phillips, \& Haas, } \\
\text { 2006a }\end{array}$ & $\begin{array}{l}5596 \text { Medicare } \\
\text { beneficiaries }\end{array}$ & $\begin{array}{l}\text { Panel Survey, nationally representative sample } \\
\text { (MEPS-HC 1996-2000); multiple inferential } \\
\text { statistic }\end{array}$ & $\begin{array}{l}\text { Estimation of change of OOPP for drugs after Part } \\
\text { D implementation; Findings: income }\end{array}$ \\
\hline $\begin{array}{l}\text { Goldman \& } \\
\text { Zissimopoulos, } \\
\text { 2003b }\end{array}$ & $\begin{array}{l}7836 \text { Medicare } \\
\text { beneficiaries }\end{array}$ & $\begin{array}{l}\text { Cross sectional survey of } 4 \text { th wave of Panel } \\
\text { survey (HRS 1998); inferential statistic }\end{array}$ & $\begin{array}{l}\text { Examination of OOPP health-care spending; } \\
\text { Findings: income }\end{array}$ \\
\hline $\begin{array}{l}\text { Guidry, Aday, Zhang, } \\
\& \text { Winn, 1998b }\end{array}$ & $\begin{array}{l}593 \text { Texan cancer } \\
\text { patients }\end{array}$ & $\begin{array}{l}\text { analytical cross-sectional survey; inferential } \\
\text { statistic }\end{array}$ & $\begin{array}{l}\text { Prevalence of barriers to cancer treatment; } \\
\text { Findings: income }\end{array}$ \\
\hline $\begin{array}{l}\text { Hwang, Weller, Ireys, } \\
\& \text { Anderson, 2001a }\end{array}$ & $\begin{array}{l}22.326 \text { patients with } \\
\text { chronic condition }\end{array}$ & cross-sectional survey (MEPS 1996); descriptive & $\begin{array}{l}\text { Impact of chronic condition \& demographics on } \\
\text { OOPP spending; Findings: sex }\end{array}$ \\
\hline $\begin{array}{l}\text { Klein, Turvey, \& } \\
\text { Wallace, } 2004 i\end{array}$ & $\begin{array}{l}6535 \text { participants of } \\
\text { AHEAD-study }\end{array}$ & $\begin{array}{l}\text { cross-sectional study of } 2 \text { nd wave of AHEAD } \\
\text { study 1997; inferential statistic }\end{array}$ & $\begin{array}{l}\text { Reasons for delay in medication use because of } \\
\text { cost; Findings: income, sex }\end{array}$ \\
\hline $\begin{array}{l}\text { Lapsley, March, } \\
\text { Tribe, Cross, \& } \\
\text { Brooks, 2001a }\end{array}$ & $\begin{array}{l}113 \text { patients with } \\
\text { Osteo-arthritis in } \\
\text { Australia }\end{array}$ & prospective-cohort study; inferential statistic & $\begin{array}{l}\text { OOPP expenditures related to osteo-arthritis; } \\
\text { Findings: sex }\end{array}$ \\
\hline $\begin{array}{l}\text { McGarry \& Schoeni, } \\
\text { 2005b }\end{array}$ & $\begin{array}{l}3821>70 \text { years old } \\
\text { Americans }(271 \\
\text { widowers, } 3550 \\
\text { married) }\end{array}$ & $\begin{array}{l}\text { national panel survey (2 Waves) (HRS); } \\
\text { descriptive }\end{array}$ & $\begin{array}{l}\text { Financial gap between widowed and married } \\
\text { Elders; Findings: sex }\end{array}$ \\
\hline $\begin{array}{l}\text { Miller \& Champion, } \\
\text { 1993a }\end{array}$ & 161 women & $\begin{array}{l}\text { convenience sample, mailed survey; inferential } \\
\text { statistic }\end{array}$ & $\begin{array}{l}\text { Relationship of patient's characteristics and } \\
\text { mammography utilization; Findings: income, } \\
\text { education }\end{array}$ \\
\hline $\begin{array}{l}\text { Mitchell, Mathews, } \\
\text { Hunt, Cobb, \& } \\
\text { Watson, 2001a }\end{array}$ & $\begin{array}{l}499 \text { patients with at } \\
\text { least one regular } \\
\text { prescription medication }\end{array}$ & $\begin{array}{l}\text { cross-sectional survey; mutliple inferential } \\
\text { statistic }\end{array}$ & $\begin{array}{l}\text { extent of mismanaging of prescription drugs } \\
\text { among rural Elders; Findings: income }\end{array}$ \\
\hline $\begin{array}{l}\text { Mojtabai \& Olfson, } \\
2003 c\end{array}$ & $\begin{array}{l}10.413 \text { Medicare } \\
\text { beneficiaries }\end{array}$ & $\begin{array}{l}\text { cross-sectional (HRS 2000); multiple inferential } \\
\text { statistic }\end{array}$ & $\begin{array}{l}\text { Association between drug coverage \& adherence; } \\
\text { cost-related poor adherence \& health outcomes; } \\
\text { Findings: income }\end{array}$ \\
\hline $\begin{array}{l}\text { Ness, Cirillo, Weir, } \\
\text { Nisly, \& Wallace, } \\
\text { 2005b }\end{array}$ & $\begin{array}{l}1099 \text { participants of } \\
\text { HRS study }\end{array}$ & cross-sectional (HRS 2000); inferential statistic & $\begin{array}{l}\text { Correlates of complementary \& alternative } \\
\text { medicine (CAM) utilization among Elders; Findings: } \\
\text { sex }\end{array}$ \\
\hline $\begin{array}{l}\text { Pourat, Rice, } \\
\text { Kominski, \& Snyder, } \\
\text { 2000d }\end{array}$ & $\begin{array}{l}15.103 \text { Medicare } \\
\text { beneficiaries }\end{array}$ & cross-sectional (MCBS 1996); inferential statistic & $\begin{array}{l}\text { Comparison of supplemental insurances to } \\
\text { examine impact of socioeconomics; Findings: } \\
\text { income, education }\end{array}$ \\
\hline $\begin{array}{l}\text { Rector \& Venus, } \\
2004 a\end{array}$ & $\begin{array}{l}1500 \text { Medicare+Choice } \\
\text { plan beneficiaries }\end{array}$ & $\begin{array}{l}\text { cross-sectional, random sample in eight } \\
\text { Medicare+Choice Plans; inferential statistic }\end{array}$ & $\begin{array}{l}\text { Influence of drug benefits on affordability for } \\
\text { beneficiaries; Findings: income }\end{array}$ \\
\hline $\begin{array}{l}\text { Rice \& Desmond, } \\
\text { 2006e }\end{array}$ & $\begin{array}{l}9278 \text { Medicare } \\
\text { beneficiaries }\end{array}$ & cross-sectional (SIPP 2001); descriptive & $\begin{array}{l}\text { Number and characteristics of Medicare } \\
\text { beneficiaries excluded from low-income subsidies } \\
\text { because of failed asset test; Findings: education, } \\
\text { sex }\end{array}$ \\
\hline
\end{tabular}


Table 1: Overview of studies reviewed (in alphabetical order) (Continued)

\begin{tabular}{|c|c|c|c|}
\hline Riley, 2008b & $\begin{array}{l}4000 \text { Medicare } \\
\text { beneficiaries at a time }\end{array}$ & $\begin{array}{l}\text { panel } 4 \text { waves (MCBS 1992, 96, 2000, 04); } \\
\text { inferential statistic }\end{array}$ & $\begin{array}{l}\text { Trends in OOPP health-care costs for MediCare } \\
\text { beneficiaries; Findings: income }\end{array}$ \\
\hline $\begin{array}{l}\text { Rogowski, Lillard, \& } \\
\text { Kington, 1997b }\end{array}$ & 996 Elders & $\begin{array}{l}\text { cross-sectional (PSID 1990); multiple inferential } \\
\text { statistic }\end{array}$ & $\begin{array}{l}\text { Amount \& influence of supplemental insurance on } \\
\text { burden of prescription drug OOPP costs; Findings: } \\
\text { income, education, sex }\end{array}$ \\
\hline $\begin{array}{l}\text { Sambamoorthi, } \\
\text { Shea, \& Crystal, } \\
2003 b\end{array}$ & $\begin{array}{l}8814 \text { Medicare } \\
\text { beneficiaries }\end{array}$ & $\begin{array}{l}\text { cross-sectional (MCBS 1997); multiple } \\
\text { inferential statistic }\end{array}$ & $\begin{array}{l}\text { Total and OOPP burden for prescription drugs in } \\
\text { relation to characteristics of elderly population; } \\
\text { Findings: income, education }\end{array}$ \\
\hline $\begin{array}{l}\text { Saver, Doescher, } \\
\text { Jackson, \& Fishman, } \\
\text { 2004d }\end{array}$ & $\begin{array}{l}4492 \text { Medicare+Choice } \\
\text { enrollees }\end{array}$ & $\begin{array}{l}\text { cross-sectional survey and administrative data } \\
\text { from Medicare, 2000; multiple inferential } \\
\text { statistic }\end{array}$ & $\begin{array}{l}\text { Relationship between drug benefit status \& access } \\
\text { to medications }+ \text { influence of income; Findings: } \\
\text { income, education }\end{array}$ \\
\hline $\begin{array}{l}\text { Selden \& Banthin, } \\
\text { 2003b }\end{array}$ & $\begin{array}{l}5733(1987), 2549 \\
(1996)>65 \text { years old } \\
\text { beneficiaries }\end{array}$ & $\begin{array}{l}\text { stratified random samples (NMES } 1987 \text { and } \\
\text { MPES 1996), longitudinal; descriptive }\end{array}$ & $\begin{array}{l}\text { Amount health-care burden for Elders; Findings: } \\
\text { income, sex }\end{array}$ \\
\hline $\begin{array}{l}\text { Soumerai et al., } \\
2006 a\end{array}$ & $\begin{array}{l}13.835 \text { Medicare } \\
\text { beneficiaries }\end{array}$ & $\begin{array}{l}\text { stratified, multistage sample (MCBS 2004), } \\
\text { cross-sectional; multiple inferential statistic }\end{array}$ & $\begin{array}{l}\text { Prevalence of cost-related medication non- } \\
\text { adherence prior to Medicare Part D; Findings: } \\
\text { income }\end{array}$ \\
\hline $\begin{array}{l}\text { Wei, Akincigil, } \\
\text { Crystal, \& } \\
\text { Sambamoorthi, } \\
2006 a\end{array}$ & $\begin{array}{l}76.440 \text { person-years } \\
\text { ( } 30.375 \text { beneficiaries) of } \\
\text { Medicare beneficiaries }\end{array}$ & $\begin{array}{l}\text { longitudinal (MCBS 1992-2000); multiple } \\
\text { inferential statistic }\end{array}$ & $\begin{array}{l}\text { Gender differences in OOPP expenditures \& burden } \\
\text { for medication; Findings: sex }\end{array}$ \\
\hline
\end{tabular}

Index for Gross Domestic Product (US Census Bureau 2010). The following information was systematically extracted (see Table 1): authors, year of publication, sample size indicating the validity of the article (varying from 113 to $30,791,751$ persons), study design, analyzed outcome, key findings stratified according to income, education and gender, and confounders controlled for.

\section{Presentation of findings}

This review is structured as follows: every socio-demographic variable has its own chapter describing its association with OOPP. As income contains the most information, the respective chapter is further structured by overall expenditures, and their biggest share, prescription drugs. Furthermore, details on impacts like insurance types or cost-reducing strategies are reported. After describing the association of education and sex with OOPP, a conclusion at the end of this review summarizes all findings, confronts them with theories to put them in scientific perspective, and gives implications.

\section{Results}

\section{Reviewed Articles}

995 papers were found via PubMed, and 17 papers were found via bibliographic search in reference lists of eligible articles, resulting in a total of 1012 studies. After exclusion of studies not focusing on out-of-pocket payments for people 65 years of age or older, 217 studies remained. Out of these, 29 articles remained containing relevant information concerning education, sex and/or income in relation to out-of-pocket payments for people $65+$ (as illustrated in Figure 1). Included are 11 longitudinal and 18 cross-sectional surveys, of which 9 articles use the MCBS (Medicare Current Beneficiary Survey), making it the most utilized source of data. Five studies are purely descriptive [3-7], while the remaining 24 use inferential statistics to test differences in out-of-pocket payments between income, education and gender groups. Of these, 14 controlled for confounders, meaning independent control variables were evaluated (for respective confounders in articles see columns in Tables 2,3 and 4). The articles used in this review originate from 1993-2009, from which 21 were published before the implementation of the Medicare Prescription Drug, Improvement, and Modernization Act of 2003, an important break marking the inclusion of a voluntary drug benefit (Part D), taking effect in January 2006 [8]. Studies varied in analysis of absolute expenditures and its relation to income [9-11], or just focusing on the burden $[7,12,13]$.

\section{Income \\ Overall expenditures}

Concerning absolute expenditures, Goldman et al. [9] found that mean yearly OOPP in 1998 were slightly higher for people with high income (above $\$ 49250 /$ year) than for those with low income (less than $\$ 15969 /$ year): $\$ 2821$ against $\$ 2346$. A similar situation can be observed for high wealth (above \$405.554 assets) compared to low wealth beneficiaries (less than \$52.595): \$2857 against $\$ 2551$. Considering OOPP in relation to income, Crystal et al. [12] found that in 1995 low-income beneficiaries had lower absolute payment amounts, but faced a significantly higher burden. The lowest income quintile is most affected by high OOPP: in contrast to the top quintile, they spent $31.5 \%$ of their yearly income (\$1639) 
compared to $8.5 \%$ (\$3219) in the top quintile. Selden et al. [7] confirmed this finding for 1996: while $19.6 \%$ of families living below the poverty line faced expenditures of at least $40 \%$ of their household income, only $4.8 \%$ of those owning $200 \%$ of the poverty line and more belong to this group. When wealth is included as a variable increasing income and spending possibilities of the 65+ population, Goldman et al. [9] showed that in 1998 the lowest quartile spent on average $17 \%$ of their annual wealth, while the top quartile only less than $1 \% .10 \%$ of the bottom quartile even spent $43 \%$ or more in two years. The development over time supports this argument. Riley [13] found an overall OOPP increase of $0.7 \%$ from 1992 to 2004, which was skewed in regard to income quartiles: while the highest quartile experienced a rise of $0.8 \%$, the second lowest quartile was hardest affected by an increase of $2.3 \%$. The lowest quartile is protected by supportive Medicaid coverage.

\section{Prescription Drugs}

Regarding absolute expenditures, Sambamoorthi et al. [10] found only slight differences in mean OOPP for different income groups in 1997: while those living above $200 \%$ of the poverty line faced payments of $\$ 447$ for their prescription drugs, those below had to pay $\$ 442$. Rogowski et al. [11] calculated out-of-pocket drug expenditures at $\$ 390$ for high-, $\$ 492$ for middle-, and $\$ 850$ for low-income beneficiaries. Concerning the burden of prescription drugs use, Rogowski et al. [11] found that the overall distribution of OOPP was highly skewed in 1997: $55 \%$ of beneficiaries spent $1 \%$ or less, while $1 \%$ of patients spent more than $25 \%$ of their yearly household income on prescription drugs. The same study also shows that the burden of prescription drug costs for high-income beneficiaries was around $0.6 \%$, and $1.6 \%$ or even $5.9 \%$ for middle and low incomes respectively, resulting in a ten times difference between income groups. According to Sambamoorthi et al. [10], nearly $8 \%$ of beneficiaries spent more than $10 \%$ of their income on prescription drugs only. While $2.4 \%$ of those living above $200 \%$ of the poverty level were concerned, $13.4 \%$ of beneficiaries living below this mark were affected.

\section{Insurance type}

In this context, a decisive argument is the type of insurance that can be afforded, identifying income as highest influence on choice, and therefore finally on OOPP. Following the 1995 MCBS (Medicare Current Beneficiary Survey), approximately $65 \%$ of Medicare beneficiaries had supplemental, prescription drug covering insurance [3]. As Dowd et al. [14] point out: those with the lowest income are most likely the ones not able to afford adequate insurance. Widespread basic Medicare coverage is the cheapest way to be insured (low premiums), as long as there are no health expenditures (high deductibles and co-insurance rates), which is most likely to happen to exactly these subgroups. Pourat et al. [15] show that with rising income, the proportion of beneficiaries with supplemental insurance rises. Among people relying on basic Medicare fee-for-service, only $5 \%$ have yearly incomes above $\$ 32.561$, but $17 \%$ have incomes under $\$ 13.024$. Adams et al. [16] found that state- and employer-sponsored drug coverage, and therefore lower OOPP, lead to a higher consumption of clinically essential drugs. Confirming this finding, Fahlman et al. [17] found that increasing levels of household income correlated with a $21 \%$ increase of prescriptions and a $25 \%$ increase in mean OOPP. The implementation of Medicare Part D in 2006 led to comparable absolute savings for all beneficiaries. Gellad et al. [18] found the overall out-of-pocket costs to decline $\$ 237$ on average, even $\$ 501$ for seniors without employer-sponsored drug coverage. But in relation to income, the Donut Hole is disadvantaging those 3.4 million low-income seniors who reached it in 2007, having the same costs as highincome beneficiaries, but higher burdens. Considering this, Medicare Part D is not able to reduce barriers to adequate medication use.

\section{Cost-reducing strategies}

Hence, strategies to reduce costs are prevalent in lowincome layers of society. Many Elders relying on their prescription drugs take less medication than prescribed, or do not fill their prescription to save money. This results in worse health conditions that require further treatments and therefore higher OOPP in the long run. Other strategies are accumulation of debt, utilization of medicine only in emergency cases, or asking practitioners for free samples [19]. This is emphasized by Klein et al. [8], who found that low-income Elders only insured by Medicare fee-for-service are much more likely to economize. $23.3 \%$ of the examined beneficiaries reduce the amount of medication in order not to exceed their prescription cap, stopping total adherence by as much as $16.3 \%$. $\$ 100$ higher costs per month lead to a $10 \%$ higher probability of irregular continuation. Regarding insurance coverage, Saver et al. [20] strongly associated income with having a prescription drug benefit. In $2000,25 \%$ of those without a prescription drug benefit experienced non-adherence, compared to only $17 \%$ owning such. Rector et al. [21] state that in 2002, 38\% of people with a monthly household income below $\$ 1000$ economized, while only $17 \%$ of those living with more than $\$ 4000$ did. Comparable numbers are reported by Soumerai et al [22] shortly before the implementation of Medicare Part D: beneficiaries living with less than $\$ 10.000$ yearly income showed a non-adherence prevalence of $14.5 \%$, those with incomes above $\$ 40.000$ report only $8.7 \%$. For Medicare beneficiaries living with out-of-pocket drug spending of at least \$1000 in 2000, 
Table 2 Overview of studies concerning INCOME (in alphabetical order)

\begin{tabular}{ll}
\hline Study & Key findings \\
\hline \hline $\begin{array}{l}\text { Adams, Soumerai, \& } \\
\text { Ross-Degnan, 2001a }\end{array}$ & high income $>$ good insurance $>$ lower OOPP $>$ higher drug \\
Clustein, 1995a & low income $>$ less probability of mammography
\end{tabular}

Chandra et al., 2007

Crystal, Johnson, Harman,

Sambamoorthi, \&

Kumar, 2000b

Davis, Poisal, Chulis,

Zarabozo, \& Cooper,

1999a

Dowd et al., 1994a

Fahlman, Lynn,

Doberman, Gabel, \&

Finch, 2006d

Gellad, Huskamp,

Phillips, \& Haas, 2006a

Goldman \&

Zissimopoulos, 2003b

Guidry, Aday, Zhang, \&

Winn, 1998b

Klein, Turvey, \& Wallace, $2004 \mathrm{i}$

Miller \& Champion, $1993 a$

Mitchell, Mathews, Hunt, Cobb, \& Watson, 2001a

Mojtabai \& Olfson, $2003 c$

Pourat, Rice, Kominski, \& Snyder, 2000d

Rector \& Venus, 2004a

Riley, 2008b

Rogowski, Lillard, \& Kington, 1997b

Sambamoorthi, Shea, \& Crystal, 2003b

Saver, Doescher, Jackson, \& Fishman, 2004d

Selden \& Banthin $2003 b$

Soumerai et al., 2006a low income $>$ high price elasticity $>$ increased hospital visits due to less prevention

average OOPP burden: 19\% (lowest quintile: 31.5\%, top quintile: $8.5 \%)$

high income $>$ best insurance $>$ lowest OOPP

high income $>$ best insurance $>$ lowest OOPP

high income $>$ high utilization \& OOPP

Medicare Part D > general cost decline, but: high incomes advantaged through lower burden in Donut Hole

high income $>$ high absolute OOPP, but lower burden (highest quartile: 1\% OOPP of income, lowest: 17\% (up to $43 \%)$; hardest hit: those shortly above limit of Medicaid support)

disadvantages for minorities (lower income, bad insurance, higher costs, less treatments)

low income $>$ bad insurance $>$ high OOPP $>$ less prevention $>$ more illnesses $>$ more OOPP $>$ more cost-reducing strategies $>$ high follow-up costs (each $+100 \$ /$ month OOPP $>+10 \%$ of unregular use)

high income $>$ high utilization \& drug adherence

less income $>$ less medication adherence due to OOPP > worse health status \& less health consciousness $>$ higher OOPP > less adherence

lower income $>$ less adherence

low income $>$ less supplemental prescription drug coverage $>$ high OOPP

low income $>$ more cost induced delay or stop of medication utilization $(<\$ 1000$ monthly household income: $38 \%,>\$ 4000: 17 \%$

1992-2004: absolute OOPP up by $22.5 \%$; highest burden: second lowest quartile $>$ no Medicaid

low income $>$ higher expenditures \& higher burden: 5,45,9\%, middle income: $1.6 \%$, highest income: 0,6\%; insurance coverage reduces amount spent by $50 \%$; cost distribution highly skewed: $55 \%$ spend $1 \%$ or less, $1 \%$ spend $25 \%$ of yearly income

Absolute OOPP nearly equal, but: low income $>$ higher burden (+10\% burden: <200\% of poverty level: $13.4 \%$, >200\%: $2.4 \%$

high income $>$ higher probability of drug benefit (25\% vs. $17 \%)>$ more adherence

lower income $>$ higher burden: +40\% burden 1987 (1996) (below poverty line: $20.9 \%$ (19.6\%), >200\% of p.l.: 3.8\% (4.8\%)) low income $>$ less drug adherence $(<\$ 10.000$ yearly income: $14.5 \%,>\$ 40.000: 8.7 \%$

\section{Confounders controlled for}

age, race, education, self-rated health status, total Medicare Part B reimbursement in 1991, smoking status, living arrangement

type of insurance plan, age, spending tercile, Charlson Index, health status

sex, race, age, education, marital status, self-reported health status, number of medical conditions, number of ADL \& IADL impairments, insurance coverage

none

age, sex, marital status, education, living arrangements, number \& proximity of living children, health insurance, self-reported health condition

race, sex, Charlson Index, age, insurance type

race, chronic conditions, insurance coverage

none

none

none

none

age, race, education, residential status, health status, medication profile

age, sex, race, education, marital status, employment, insurance coverage

none

none

none

age, sex, race, education, residential status, marital status, insurance coverage, health status

sex, race, age, education, marital status, insurance coverage, self-rated health status, place of residence

age, race, sex, education, household configuration, insurance coverage, self-rated health status

none

sex, age, race, education, self-rated health status, insurance coverage 
Mojtabai et al. [23] stated that only 6\% of those living at least $400 \%$ above the poverty line economized, while $21 \%$ below poverty line admitted to doing so.

\section{Education}

Several articles refer to education as a significant cause for differences among older persons and their burden of OOPP for medical services. The main finding is that the lower the level of education, the higher the burden becomes [10-12]. Lower education may lead to lower income and lack of employer based health programs $[15,20]$. Concerning the burden of overall out-of-pocket costs in 1995, Crystal et al. [12] found that beneficiaries with college degrees spent $12.8 \%$ of their income on health-care, while those without a high school diploma spent $21.4 \%$. Focusing on burden of prescription drugs costs only, Rogowski et al. [11] found that beneficiaries with less than 12 years of education paid $4.5 \%$ of their incomes on prescription drugs in 1990, while those with more than 12 years of education only $1.6 \%$. As suggested before, this was mainly caused by lower retirement incomes and less prevalence of private insurance. Sambamoorthi et al. [10] found that $12.1 \%$ of those without a high school diploma had to pay more than $10 \%$ of their income on prescription drugs in 1997, but only $3.9 \%$ of seniors with college education had to. Conversely, a burden of $0-5 \%$ was determined for $56.9 \%$ of those without a high school diploma, while $77.8 \%$ of college graduates belonged to this group. Increments of education confirm this trend proportionally. Regarding insurance coverage, Pourat et al. [15] found in 2000 that the likelihood of an employment-based or MediGap coverage is raised by better education, while a poor education increases the probability of basic Medicare feefor-service insurance only, or no coverage at all, leading to higher OOPP in case of morbidity. Saver et al. [20] confirmed this observation in 2004: only $39 \%$ of those without coverage faced monthly expenditures below $\$ 50$, while $79 \%$ of patients with private prescription coverage did. Equivalently, $8 \%$ of not-covered beneficiaries faced more than $\$ 100$ per month, while nobody of the second group had to pay this amount. The poorest are secured by Medicaid, but the ones shortly above the income limit for eligibility are confronted with catastrophic costs that eat up all their savings before Medicaid steps in [9]. Another point is the Medicare Part D asset test, denoting specific income and asset thresholds set to qualify for low-income subsidies [6]. Those lowincome seniors failing the test mostly have better education than those who qualify for subsidies (college degree: 9.7\% vs. $4.4 \%$ ). But because approximately $70 \%$ of those only have incomes less than $135 \%$ of the federal poverty line, and around $50 \%$ of them only have assets less than $\$ 35.000$ above the allowing thresholds. These assets would not pay a single year of nursing home care. Compared to beneficiaries without any assets, they have to deal with higher OOPP without governmental support, and in relation to those with higher incomes and larger assets, they have to pay similar OOPP with less means [6]. Furthermore, a low educational standard is associated with lower utilisation of preventive measures. In various studies [24,25] clarify that a college degree is highly associated with preventive behaviour like mammography. Not using preventive measures finally leads to higher OOPP due to worse health status.

\section{Sex}

There are certain gender related differences concerning OOPP. Selden et al. [7] found that in women, prevalence of high burden for medical services is significantly higher than in men for all age groups. For example, $12.2 \%$ of females aged 75 years and older faced burdens larger than at least $40 \%$ of after-tax disposable income in 1996, but only $9.2 \%$ of men. Concerning prescription drugs, in 1995 women had $18 \%$ more annual OOPP than men (\$551 vs. \$454) [26]. In a longitudinal study from 1992-2000, Wei et al. [27] found the similar inequality (\$526 vs. \$432) in expenditures. Regarding the burden of OOPP for prescription drugs, Wei et al. describe a gender difference of $28 \%$ (4.4\% vs. $3.2 \%$ ) [27]. While finding equal absolute OOPP in 1996, Rogowski et al. [11] approve the finding that women have a higher relative burden (3.3\% vs. $2.8 \%)$. Sambamoorthi et al. [10] found that $9.4 \%$ of women faced a burden of at least $10 \%$ of their income for OOPP on prescription drugs, compared to only $5.7 \%$ in men. The more distinct the gender differences in health status and income are, the higher the difference in burden appears. One reason for the differences is that women are less likely to be employed, and thereby generate less wealth. Even if women pursue a career, on average they have significantly lower income than men. Wei et al. stated that in 1999 the mean income for women aged at least 65 years was $\$ 19.097$, compared to $\$ 35.676$ for men [27]. $26 \%$ of female Medicare beneficiaries live below the federal poverty line, whereas only $11 \%$ of men. Being less often employed also means fewer possibilities to be covered by an employer-financed supplemental insurance (including drug coverage) to protect women from high burdens for out-of-pocket medical expenses [26]. Aggravating this is the fact that women consume more medication than men [27], for example for not incurred complementary and alternative medicine [28]. Considering that women in general have to pay more out-ofpocket for medication and special equipment, as Lapsley et al. illustrate [29], they are more likely to rely on the aforementioned strategies to reduce costs [8]. Furthermore, gender-specific morbidities like breast cancer 


\section{Table 3 Overview of studies concerning EDUCATION (in alphabetical order)}

\begin{tabular}{|c|c|c|}
\hline Study & Key findings & Confounders controlled for \\
\hline Blustein, 1995a & low education > less probability of mammography & $\begin{array}{l}\text { age, race, income, self-rated health status, total Medicare Part } \\
\text { B reimbursement in 1991, smoking status, living } \\
\text { arrangement }\end{array}$ \\
\hline $\begin{array}{l}\text { Crystal, Johnson, } \\
\text { Harman, Sambamoorthi, } \\
\text { \& Kumar, 2000b }\end{array}$ & $\begin{array}{l}\text { OOPP burden with no high school: } 21.4 \% \text {, college degree: } \\
12.8 \%\end{array}$ & $\begin{array}{l}\text { gender, race, age, income, marital status, self-reported health } \\
\text { status, number of medical conditions, number of } A D L \& \\
\text { IADL impairments, insurance coverage }\end{array}$ \\
\hline $\begin{array}{l}\text { Miller \& Champion, } \\
\text { 1993a }\end{array}$ & $\begin{array}{l}\text { college degree significant for mammography \& physician } \\
\text { visits }>\text { less OOPP burden in the long-term }\end{array}$ & none \\
\hline $\begin{array}{l}\text { Pourat, Rice, Kominski, } \\
\text { \& Snyder, 2000d }\end{array}$ & better education $>$ better insurance $>$ less OOPP & none \\
\hline Rice \& Desmond, 2006e & $\begin{array}{l}\text { higher education than lowest income group > income } \\
\text { above Medicaid limit > same OOPP as high income group, } \\
\text { but less education \& income; higher OOPP than subsidy } \\
\text { group for having higher education \& income }\end{array}$ & none \\
\hline $\begin{array}{l}\text { Rogowski, Lillard, \& } \\
\text { Kington, 1997b }\end{array}$ & $\begin{array}{l}\text { better education }>\text { less OOPP burden (higher income, } \\
\text { better insurance): }>12 \text { years: } 1.6 \%,<12 \text { years: } 4.5 \%\end{array}$ & $\begin{array}{l}\text { age, sex, race, income, residential status, marital status, } \\
\text { insurance coverage, health status }\end{array}$ \\
\hline $\begin{array}{l}\text { Sambamoorthi, Shea, \& } \\
\text { Crystal, 2003b }\end{array}$ & $\begin{array}{l}\text { less education > higher OOPP (over } 10 \% \text { of burden without } \\
\text { high school degree: } 12.1 \% \text {, college: } 3.9 \% \text { ) }\end{array}$ & $\begin{array}{l}\text { gender, race, age, income, marital status, insurance coverage, } \\
\text { self-rated health status, place of residence }\end{array}$ \\
\hline $\begin{array}{l}\text { Saver, Doescher, } \\
\text { Jackson, \& Fishman, } \\
\text { 2004d) }\end{array}$ & $\begin{array}{l}\text { better education }>\text { more prescription drug coverage }>\text { less } \\
\text { OOPP }\end{array}$ & $\begin{array}{l}\text { age, race, sex, income, household configuration, insurance } \\
\text { coverage, self-rated health status }\end{array}$ \\
\hline
\end{tabular}

Table 4 Overview of studies concerning SEX (in alphabetical order)

\begin{tabular}{|c|c|c|}
\hline Study & Key findings & Confounders controlled for \\
\hline Blustein, 2000b & $\begin{array}{l}\text { women }>\text { rather poor ( } 26 \% \text { below poverty line, men: } 11 \%) \text {; less } \\
\text { employed }>\text { less insurance coverage }>\text { higher OOPP }(18 \% \text { higher than } \\
\text { men for drugs) }\end{array}$ & $\begin{array}{l}\text { age, race, education, self-rated health status, } \\
\text { insurance coverage }\end{array}$ \\
\hline $\begin{array}{l}\text { Fahlman, Lynn, } \\
\text { Doberman, Gabel, \& } \\
\text { Finch, 2006d }\end{array}$ & women > higher OOPP in last year of life (\$668 vs. \$586) & race, income, Charlson Index, age, insurance type \\
\hline $\begin{array}{l}\text { Hwang, Weller, Ireys, \& } \\
\text { Anderson, 2001a }\end{array}$ & $\begin{array}{l}\text { women > longer lifespan > higher probability of comorbidities > } \\
\text { higher OOPP }\end{array}$ & none \\
\hline $\begin{array}{l}\text { Klein, Turvey, \& } \\
\text { Wallace, } 2004 \mathrm{i}\end{array}$ & women $>$ higher OOPP > more cost-reducing strategies & none \\
\hline $\begin{array}{l}\text { Lapsley, March, Tribe, } \\
\text { Cross, \& Brooks, 2001a }\end{array}$ & women > higher OOPP for drugs \& devices & none \\
\hline $\begin{array}{l}\text { McGarry \& Schoeni, } \\
\text { 2005b }\end{array}$ & $\begin{array}{l}\text { women > longer lifespan > more widowhood; lowest income quartile } \\
(<\$ 12.000): 70 \% \text { of income spent in final two years for health-care } \\
\text { (average: } 30 \%) \text {; poverty rate: widows } 17 \% \text {, married Elders: } 5 \%\end{array}$ & none \\
\hline $\begin{array}{l}\text { Ness, Cirillo, Weir, Nisly, } \\
\& \text { Wallace, 2005b }\end{array}$ & women > more CAM utilization > higher OOPP & none \\
\hline $\begin{array}{l}\text { Rice \& Desmond, } \\
\text { 2006e }\end{array}$ & $\begin{array}{l}\text { women }>\text { longer lifespan: partner dies }>\text { income plummets }>\text { heir } \\
\text { above limit }>\text { no subsidies > old-age poverty; of } 46 \% \text { widowers failing } \\
\text { asset test }>46 \% \text { female }\end{array}$ & none \\
\hline $\begin{array}{l}\text { Rogowski, Lillard, \& } \\
\text { Kington, 1997b }\end{array}$ & women > equal expenditures, but higher burden (3.3\% vs. 2.8\%) & $\begin{array}{l}\text { age, income, race, education, residential status, } \\
\text { marital status, insurance coverage, health status }\end{array}$ \\
\hline $\begin{array}{l}\text { Sambamoorthi, Shea, \& } \\
\text { Crystal, 2003b }\end{array}$ & $\begin{array}{l}\text { women }>\text { higher OOPP (over } 10 \% \text { of burden }>\text { women } 9.4 \% \text {, men } \\
5.7 \% \text { ) }\end{array}$ & $\begin{array}{l}\text { income, race, age, education, marital status, } \\
\text { insurance coverage, self-rated health status, place } \\
\text { of residence }\end{array}$ \\
\hline $\begin{array}{l}\text { Selden \& Banthin, } \\
\text { 2003b }\end{array}$ & $\begin{array}{l}\text { women > higher burden (over 20\% of burden } 1987 \text { (1996): 19.6\% } \\
\text { (19.8\%), men: } 12.7 \%(15.9 \%)\end{array}$ & none \\
\hline $\begin{array}{l}\text { Wei, Akincigil, Crystal, \& } \\
\text { Sambamoorthi, 2006a }\end{array}$ & $\begin{array}{l}\text { women > lower income, more utilization, higher absolute OOPP, } \\
\text { higher burden; gender-specific illnesses > less generous benefits > } \\
\text { higher OOPP }\end{array}$ & $\begin{array}{l}\text { race, age, marital status, education, place of } \\
\text { residence, poverty status, insurance coverage, } \\
\text { health status }\end{array}$ \\
\hline
\end{tabular}


cause higher OOPP, since appropriate health-care plans have less generous benefits [27]. An additional aspect is women's longer life expectancy, thereby producing the greater likelihood for chronic diseases in general [4]. For financial issues, it is also relevant that women, due to their longer lifespan, have a higher probability become a widow. Those in the lowest income quartile (below $\$ 12.000)$ pay approximately $70 \%$ of their income in their final two years for health-care, whereas the average is around $30 \%$, leading to higher poverty rates ( $17 \%$ vs. $5 \%)$. Among other reasons, OOPP in the last year of the spouses' life and the loss of the spouses' income raise the likelihood of old age poverty for widows by $56 \%$ [5]. Rice et al. deliver proof that if widowed women benefit from an inheritance, they are very likely to be excluded from needed low-income subsidies, because their assets exceed the limit Medicare Part D foresees, so that the assets first have to be spent out-of-pocket before the federal government steps in: $46 \%$ of those failing the asset test are widowed, and almost all are female ( 93\%) [6].

\section{Discussion Findings}

Most of the reviewed studies describe inequalities in OOPP for medical services, in relation to diverging income proportions. The largest amount of OOPP can be assigned to prescription medications, leading to costinduced strategies like non-adherence, implicating further health problems. This effect is further enhanced by the widespread lack of preventive measures among low-income beneficiaries, partly caused by lack of supplemental insurance. This describes women and loweducated layers of society. Considered as percentage share, women, lower social and low-income classes are far heavier affected. While these variables explain a great part of income inequalities, which finally lead to inequalities in OOPP, they are also predictors of inequalities in their own right. For example, being female and low-educated leads to being employed less or working in worse paid jobs than higher-educated people. A cycle of low income, no supplemental insurance, less paid services, worse health and thereby financially unfeasible need is set in motion. Besides inequalities associated with lower income, several studies indicate higher out-of-pocket burdens on a genderand education-specific level. Concerning sex, genderspecific illnesses (like breast cancer or other chronic diseases that are more likely to occur due to a longer lifespan), and higher costs for medications and special equipment influence the health-care burden without being associated with income. On the education side, problems like lower awareness of a healthy lifestyle, reflecting less use of preventive measures, may constitute income-independent disadvantages. Furthermore, another effect can be observed: Neuman et al. [30] show that the implementation of Medicare Part D in 2006, resulting in a rising number of private insurers, led to a larger variety of available plans to choose from. This could have left low-educated beneficiaries in a confusing situation, making it hard to find adequate insurance options trying to face all possibilities and background information. As public health policy is unable to influence education's role in the short-term by providing information and transparency, possible approaches to a solution should be based on the strong correlation of income and education. Thus, appropriate measures ought to be largely coherent with those for income and burden, for example income thresholds according to beneficiaries' burden. Besides education, an enhanced preference of low-risk beneficiaries in popular plans could have been initiated by the insurers, leaving disadvantaged seniors aside. This could explain why despite all reform efforts since 2006, the number of about four million beneficiaries without drug coverage remains constant up to today. As several studies reviewed show the importance of access to prescription drug coverage for the amount of OOPP prior to the implementation of Medicare Part D in 2006 [10-12,14,17-20,22,23,26,27,31], its initiation should have settled this problem. But as studies analyzing data after 2006 reveal $[8,30,32]$, details like the "Donut Hole" coverage gap still remain responsible for inequalities. Based on the studies reviewed, an explanation for inequalities in OOPP by these factors remains ambiguous. Also, methodically, the diversity of controlled confounders could have caused difficulties in comparing results.

\section{Context \& theories}

To give a starting point for subsequent studies examining mechanisms causing these inequalities, hereafter, the findings will shortly be put in conjunction with relevant theories. The aim is to show what other variables could cause effects on OOPP inequalities. Mojtabai et al. [23] demonstrated that severe health problems lead to more medication, and thereby higher OOPP, resulting in a higher probability of non-adherence, poorer health and more hospitalizations, especially for those without supplemental insurance and low income paired with high OOPP. This summary is quintessential for most of the findings in this review. The coherence between high OOPP and non-adherence to medication is observed by several authors $[8,21,22]$, as well as the association of cost-induced strategies and worse health outcomes [19]. The intensification of this problem for low-income beneficiaries in a disadvantageous insurance situation is also evident [22]. As this finding refers to income only, Sambamoorthi et al. [10] put other variables in perspective 
by arguing that generation-comprehensive predispositions may impact actual developments. Parents' low income leads to poor education. A corresponding workplace, which results in low income (and a lack of sufficient assets), leads to a lifestyle detrimental to good health and preventive measures, which itself leads to high OOPP that one cannot afford. Reinforcing this development, inequalities intensify with age. The connection of low education, poorly paid jobs and corresponding income and insurance, is supported by several studies reviewed [8,25]. Also, coherence is found between less income and a lack of awareness of health, reflecting less adherence to medication and preventive measures [19]. The resulting effect of higher OOPP has also been demonstrated [15,22]. To put all questioned variables in perspective, several articles confirm that being female is an additional aspect worsening the situation by, for example, lower income and a longer lifespan $[5,6,17,26]$. So generally, Sambamoorthi et al.'s thesis can be confirmed. But it also becomes clear that the variables income, education and gender cannot explain the whole context independently, as other aspects throw different light on the argumentation. Ahrens [33] also identifies overall working-, living- and environmental circumstances as main influences on health status. He states that predisposing factors (age, sex, congenital diseases), medical infrastructure (quantity and quality, financial means), social status (lifestyle, income, education) and comprehensive variables (education system, environmental quality, labour conditions) as individual and systematic circumstances finally determine the means to deal with high OOPP. Therefore, it can be assumed that a concluding bottom line of coherence cannot be drawn solely on the basis of income, education and gender, as numerous other variables seem to bear an unexplored amount of influence, whose extent has to be analyzed in future studies.

\section{Approaches to a solution}

Finally, a short windup addressing possible approaches to overcome inequalities in burden will be provided. Although beneficiaries can influence their situation by, for example, granting preventive measures a high priority, their information deficit puts them in a dependent position. Their state is defined by the physician's diagnosis, who profits from the divide in information, competence and a lack of transparency concerning the iatrogenic costs [33]. This may be a point to exercise pressure, by developing a system not paying the physician by the number of measures prescribed, but by the quality of care, reflecting his patients' health status. McCormick et al. [34] found that only 9.1\% of US- physicians probed support the status quo, while reform proposals like adding tax credits or tax penalties (49.2\%) or single payer NHI programs $(41.6 \%)$ are favoured. When raising OOPP is necessary due to fiscal reasons, it should occur in relation to the patient's income. Chandra et al. further suggest that one regards health status as a second factor to determine the incomerelated limit of cost-sharing in order to protect chronically ill patients from catastrophic expenditures [31]. The focus should lie on equal burdens, not equal expenditures. By doing so, inequalities could be alleviated. Another problem to solve is "cream skimming", the insurer's selection of low-risk beneficiaries. As this issue is intensified by an increasing number of plans to choose from, the variety of plans should be reduced to a reasonable and transparent extent. Also, the government could limit the influence of private insurers on the market, so that high-income beneficiaries cannot exclude themselves from the solidarity system, leaving society socially unbalanced [30]. Additionally, the inequality problems in connection with the Donut Hole $[8,18]$ and the Medicare Part D asset test [6] should be identified as a financial threat. If OOPP have to be imposed to stabilize the budget situation for future tasks, their implementation should be carefully thought over, with great importance attached to socially balanced arrangements.

\section{Limitations}

Most of the studies included in the review contained a number of limitations, reflecting in a confined validity of this article, namely possible biases in inferring causal relationships from cross-sectional data, response and recall errors as a potential concern with survey data, the different approaches of data collection in reviewed surveys, and the reliability of self-reported data used in several studies. Further, comparability may be limited due to diverse confounders controlled for. Also, the impact of the implementation of Medicare Part D in 2006 and the effects of its design can not be totally clarified.

\section{Conclusions}

As evidently shown in this systematic review, income has a significant influence on the amount of OOPP resting on the beneficiary, especially concerning the inequality of burden manifesting a profound disadvantage for low-income patients. Not only resulting in unfeasible financial difficulties, but also in worse health status, this inequity creates a vicious cycle hard to escape. Secondly, while most studies found educational and gender inequalities to be associated with income, there might also be effects induced solely by education; for example, an unhealthy lifestyle leading to higher payments for 
lower-educated people, or exclusively gender-induced effects, like sex-specific illnesses. Based on the considered studies, an explanation for inequalities in OOPP by these factors remains ambiguous.

\section{Acknowledgements}

This work is part of Esther-Net and was supported by the German Federal Ministry for Education and Research [grant number: 01 ET0719 (Esther-Net)] The German Federal Ministry for Education and Research had no further role in the study design; in the collection, analyses and interpretation of data; in writing the report; and in the decision to submit the paper for publication. The publication of study results was not contingent on the sponsor's approval.

\section{Author details}

${ }^{1}$ University of Leipzig, Health Economics Research Unit, Department of Psychiatry, Liebigstr. 26, 04103 Leipzig, Germany. ${ }^{2}$ Department of Medical Sociology and Health Economics, University Medical Center HamburgEppendorf, Martinistr. 52, 20246 Hamburg, Germany. ${ }^{3}$ University of Leipzig, Department of Psychiatry, Semmelweisstr. 10, 04103 Leipzig, Germany. ${ }^{4}$ Division of Clinical Epidemiology and Aging Research, German Cancer Research Center, Bergheimer Str. 20, 69115 Heidelberg, Germany.

\section{Authors' contributions}

SC conceived the study, participated in its design and implementation, and drafted and finalized the manuscript. DH conceived the study, participated in its design and implementation, and helped to draft the manuscript. HM and $T L$ contributed to the manuscript and with references. ER helped to draft the manuscript and commented the manuscript. HHK conceived the study, participated in its design and implementation, and helped to draft the manuscript. All authors read and approved the final draft of the manuscript.

\section{Competing interests}

The authors declare that they have no competing interests.

Received: 16 February 2010 Accepted: 11 August 2010

Published: 11 August 2010

\section{References}

1. OECD: Health Data 2009. Paris, Organization for Economic Co-operation and Development 2009, Ref Type: Report.

2. Getzen TE: Health Economics: Fundamentals and Flow of Funds. New York: John Wiley \& Sons, Inc. 1997.

3. Davis M, Poisal J, Chulis G, Zarabozo C, Cooper B: Prescription drug coverage, utilization, and spending among Medicare beneficiaries. Health Aff (Millwood) 1999, 18:231-243.

4. Hwang W, Weller W, Ireys $H$, Anderson G: Out-of-pocket medical spending for care of chronic conditions. Health Aff (Millwood) 2001, 20:267-278.

5. McGarry K, Schoeni RF: Widow(er) poverty and out-of-pocket medical expenditures near the end of life. J Gerontol B Psychol Sci Soc Sci 2005, 60: S160-S168.

6. $\quad$ Rice $T$, Desmond $K$ : Who will be denied Medicare prescription drug subsidies because of the asset test? Am J Manag Care 2006, 12:46-54

7. Selden TM, Banthin JS: Health care expenditure burdens among elderly adults: 1987 and 1996. Med Care 2003, 41:|l|13-|||23.

8. Klein D, Turvey C, Wallace R: Elders who delay medication because of cost: health insurance, demographic, health, and financial correlates. Gerontologist 2004, 44:779-787.

9. Goldman DP, Zissimopoulos JM: High out-of-pocket health care spending by the elderly. Health Aff (Millwood) 2003, 22:194-202.

10. Sambamoorthi U, Shea D, Crystal S: Total and out-of-pocket expenditures for prescription drugs among older persons. Gerontologist 2003, 43:345-359.

11. Rogowski J, Lillard LA, Kington R: The financial burden of prescription drug use among elderly persons. Gerontologist 1997, 37:475-482.

12. Crystal S, Johnson RW, Harman J, Sambamoorthi U, Kumar R: Out-of-pocket health care costs among older Americans. J Gerontol B Psychol Sci Soc Sci 2000, 55:S51-S62.
13. Riley GF: Trends in out-of-pocket healthcare costs among older community-dwelling Medicare beneficiaries. Am J Manag Care 2008, 14:692-696.

14. Dowd B, Moscovice I, Feldman R, Finch M, Wisner C, Hillson S: Health plan choice in the Twin Cities Medicare market. Med Care 1994, 32:1019-1039.

15. Pourat N, Rice T, Kominski G, Snyder RE: Socioeconomic differences in Medicare supplemental coverage. Health Aff (Millwood) 2000, 19:186-196.

16. Adams AS, Soumerai SB, Ross-Degnan D: Use of antihypertensive drugs by Medicare enrollees: does type of drug coverage matter? Health Aff (Millwood) 2001, 20:276-286.

17. Fahlman C, Lynn J, Doberman D, Gabel J, Finch M: Prescription drug spending for Medicare+Choice beneficiaries in the last year of life. $J$ Palliat Med 2006, 9:884-893.

18. Gellad WF, Huskamp HA, Phillips KA, Haas JS: How the new medicare drug benefit could affect vulnerable populations. Health Aff (Millwood) 2006, 25:248-255.

19. Mitchell J, Mathews HF, Hunt LM, Cobb KH, Watson RW: Mismanaging prescription medications among rural elders: the effects of socioeconomic status, health status, and medication profile indicators. Gerontologist 2001, 41:348-356.

20. Saver BG, Doescher MP, Jackson JE, Fishman P: Seniors with chronic health conditions and prescription drugs: benefits, wealth, and health. Value Health 2004, 7:133-143.

21. Rector TS, Venus PJ: Do drug benefits help Medicare beneficiaries afford prescribed drugs? Health Aff (Millwood) 2004, 23:213-222

22. Soumerai SB, Pierre-Jacques M, Zhang F, Ross-Degnan D, Adams AS, Gurwitz J, et al: Cost-related medication nonadherence among elderly and disabled medicare beneficiaries: a national survey 1 year before the medicare drug benefit. Arch Intern Med 2006, 166:1829-1835.

23. Mojtabai R, Olfson M: Medication costs, adherence, and health outcomes among Medicare beneficiaries. Health Aff (Millwood) 2003, 22:220-229.

24. Miller AM, Champion VL: Mammography in women $>$ or $=50$ years of age. Predisposing and enabling characteristics. Cancer Nurs 1993, 16:260-269.

25. Blustein J: Medicare coverage, supplemental insurance, and the use of mammography by older women. N Engl J Med 1995, 332:1138-1143.

26. Blustein J: Medicare and drug coverage: a women's health issue. Womens Health Issues 2000, 10:47-53.

27. Wei WH, Akincigil A, Crystal S, Sambamoorthi U: Gender differences in out-of-pocket prescription drug expenditures among the elderly. Research on Aging 2006, 28:427-453.

28. Ness J, Cirillo DJ, Weir DR, Nisly NL, Wallace RB: Use of complementary medicine in older Americans: results from the Health and Retirement Study. Gerontologist 2005, 45:516-524

29. Lapsley HM, March LM, Tribe KL, Cross MJ, Brooks PM: Living with osteoarthritis: patient expenditures, health status, and social impact. Arthritis Rheum 2001, 45:301-306.

30. Neuman P, Cubanski J: Medicare Part D update-lessons learned and unfinished business. N Engl J Med 2009, 361:406-414.

31. Chandra A, Gruber J, McKnight R: Patient Cost-Sharing, Hospitalization Offsets, and the Design of Optimal Health Insurance for the Elderly. NBER Working Paper Series 2007, w12972.

32. Gellad WF, Huskamp HA, Phillips KA, Haas JS: Angiotensin receptor blockers on the formularies of Medicare drug plans. J Gen Intern Med 2007, 22:1172-1175.

33. Ahrens D: Health economy and health promotion - self-responsibility for health? Gesundheitswesen 2004, 66:213-221.

34. McCormick D, Woolhandler S, Bose-Kolanu A, Germann A, Bor DH, Himmelstein DU: U.S. physicians' views on financing options to expand health insurance coverage: a national survey. J Gen Intern Med 2009, 24:526-531.

doi:10.1186/1475-9276-9-20

Cite this article as: Corrieri et al:: Income-, education- and genderrelated inequalities in out-of-pocket health-care payments for $65+$ patients - a systematic review. International Journal for Equity in Health 2010 9:20. 